\title{
CROATIAN BANKS PROFITABILITY UNDER CAPITAL REQUIREMENTS PRESSURE*
}

\author{
Ana Kundid Novokmet ${ }^{* *}$ \\ Ana Pavić ${ }^{* * *}$
}

Received: 22. 7. 2020

Original scientific paper

Accepted: 8. 1.2021

UDC 336.71:330.13

DOI https://doi.org/10.30924/mjcmi.26.si.2

\begin{abstract}
Regulating bank behavior throughout capital requirements has been a focal point of prudential regulation since the late 1980s. However, their beneficial effect on the banking sector's safety and soundness was disputed ever since their initial implementation, mainly due to an assumption that they deteriorate bank profitability and increase the odds for the enlarged risk appetites of bank managers, especially in the highly competitive financial markets. On the other hand, bank profitability is driven by many factors other than compliance with capital regulation. Concerning that, a question about the capital requirements' impact on bank profitability was raised in this paper. The dynamic panel data analysis served to examine the consequences of bank capital regulation for the Croatian banking sector profitability,
\end{abstract}

Abstract

\section{INTRODUCTION}

Banking regulation is an integral part of every financial and economic system, aimed to direct banks' shareholders, managers, and stakeholders towards a socially desirable behavior - the one that enables banks to perform various roles and provide diverse financial services which should respond to the public/ clients' needs, without distracting the banking by taking into observation 24 commercial banks in the 2011-2016 timespan. The impact of capital regulation on the return on assets and net interest margin was positive, while for the return on equity a negative relationship was found. It was concluded that banks transfer regulatory costs on their clients, which was approximated with the net interest margin. In addition, results reveal that the overall bank profitability is achieved at the expense of bank shareholders. Thus, a more cost-efficient approach to managing a bank is suggested.

Keywords: capital requirements, bank profitability, capital structure, commercial banks, dynamic panel analysis

sector safety and soundness. However, implementation of regulatory instruments in practice is not cost-free and it imposes numerous limitations to the business of banking, which, in return, might cause unintended or even adverse effects. In that sense, this paper puts in the spotlight the bank risk-weighted capital regulation i.e. its consequences for the bank managers' behavior.

\footnotetext{
* This paper is an outcome of the diploma thesis, written by A. Pavić, under the supervision of A. Kundid Novokmet at the university graduate degree program in Business Studies, course of study in Financial Management, at the Faculty of Economics, Business and Tourism, University of Split. The second section of the paper is an outcome of the doctoral thesis, written by A. Kundid.

** Ana Kundid Novokmet, PhD, Associate Professor, Faculty of Economics, Business and Tourism, University of Split, Cvite Fiskovića 5, 21000 Split, Croatia. Phone: ++385 21430 752; Fax: ++385 21430 701, E-mail: akundid@efst.hr, ORCID: https://orcid.org/0000-0002-3783-9833

***Ana Pavić, mag. oec., E-mail: pavicana45@gmail.com
} 


\section{Journal of Contemporary Management Issues}

The risk-weighted capital requirements regulation (also known under the umbrella term Basel accords) is the most important measure of regulating bank behavior since the late 1980s. The main idea behind its continuous use is that bank asset growth and risk acceptance will be permitted up to a certain level of regulatory capital, or, to be more precise, the capital adequacy ratio should not fall under $8 \%$. Namely, the bank growth and business risks need to be backed up with an adequate level and structure of bank capital to avoid morally hazardous behavior by bank shareholders and their agents i.e. bank managers. More restrictive regulatory measures, like prohibiting banks to offer certain high-risk financial services, are not in line with the financial liberalization ideology. Therefore, the capital requirements regulation will persist as the most important tool of prudential authorities worldwide despite extensive criticism on its account (see e.g. Daníelsson et al., 2001; Rodríguez, 2003; Benston, 2007; Moosa, 2010). Among other shortcomings, one unintended effect of bank capital regulation has been repeated for a long time, or, to be more precise, since Koehn and Santomero, (1980), and Kim and Santomero (1988) seminal work. They maintained that the higher levels of the most expensive source of financing, i.e. equity capital, will be compensated with larger business risk acceptance, which might destabilize, rather than (as expected) increase banking stability.

Studies on the capital requirements implications, which were performed for the banking sectors of the most developed countries, mainly went into the direction of investigating their impact on the bank asset riskiness, selection of clients, and pro-cyclicality issues, leaving a rather modest empirical background for the profitability aspect of the business of banking under capital requirements pressure. With regards to the latter, the majority of work was done in the area of testing the agency cost hypothesis (e.g. Berger and Bonaccorsi di Patti, 2006), according to which more capitalized banks are less cost-efficient, and thus record lower profitability. Nevertheless, if higher equity financing affects bank profitability positively, this is attributed to a lower risk premium and decreased cost of refinancing in the case of better solvency (so-called traditional theory of capital structure). Finally, when the positive and negative effects of certain indebtedness levels are equal, the effect of the financial structure on profitability is neutral. Examining the effects of the bank capital regulation has been a rather neglected field of research when the Croatian banking sector is in focus, regardless of whether the microeconomic or macroeconomic repercussions were under consideration. Although there is certain empirical evidence about the capital regulation impact on bank profitability (see Kundid, 2012, 2014) it is quite general and rather outdated. Therefore, with this paper, we strive to fill that gap and focus more on various aspects of bank regulatory solvency and their role in profitability achievement measured with the return on assets (as a proxy for bank managers' performance accomplishment and the overall bank profitability), return on equity (stands for bank shareholders profitability) and net interest margin (depicting the bank clients position). Furthermore, inspired by the work of Berger and Bouwman (2009), Osborne et al. (2012), de Bandt et al. (2017), Tabak et al. (2017), and de Bandt et al. (2018) our attention is focused on the time of low economic activity to reach some conclusions with regards to the question whether higher regulatory capital can be a source of comparative advantage in the period of financial hardship. At last, with a stronghold in Coccorese and Girardone (2017), we explain whether the capital 
requirements influence on the bank profitability is rooted in the credit risk channel, off-balance-sheet channel, and/or operating efficiency channel of the capital regulation.

The rest of the paper is organized as follows: the second section focuses mainly on the theory of capital structure, which is a cornerstone of studies about the riskweighted capital regulation impact on bank behavior. The third section summarizes empirical literature concerning the capital regulation consequences for the banking sector's profitability. The fourth section discloses the empirical strategy, followed by the discussion of research results on the capital regulation relevance for explaining the disparities in the Croatian banks' profitability. The last section points out the key findings and the key takeaways of this paper.

\section{IMPORTANCE OF CAPITAL STRUCTURE THEORIES FOR RESEARCH OF THE BANK CAPITAL REQUIREMENTS REGULATION}

"Any economic study of bank capital regulation requires a theory of capital structure" (Prescott, 2001, 35).

The contemporary theory of capital structure is a complex field of research, that has been developing since the late 1950s. Despite numerous explanations concerning the capital structure relevance for the business performance, it all comes down to these milestones in the theory development: the capital structure irrelevance theory (Modigliani and Miller, 1958), traditional approach to capital structure (Myers, 1984), underinvestment hypothesis, risk-shifting hypothesis and pecking order theory of capital structure (Myers, 1984; Myers and Majluf, 1984).

According to Modigliani and Miller (1958), there is no optimal capital structure, as companies' financial decisions do not influence their market value. Namely, when perfect market conditions are assumed, the weighted average cost of capital remains unchanged in the case of capital restructuring as any increase in the cheaper financial sources like debt financing will be annulled with a more expensive subordinated debt and equity financing due to an increased financial risk premium. Even though perfect market conditions are a utopian phenomenon, Modigliani and Miller's irrelevance proposition is valuable, as they focus more on the importance of the company's investment quality, rather than on financial contracts, which should be seen as transitional assets or investment offers to potential investors. Thus, three decades after his seminal paper, Miller $(1988,100)$ emphasized: "the view that capital structure is literally irrelevant or that 'nothing matters' in corporate finance, though still sometimes attributed to us, is far from what we ever actually said about the real-world applications of our theoretical propositions", but "showing what doesn't matter can also show, by implication, what does". What matters even more nowadays, since the end of one of the most severe and expensive financial crisis, are certainly the main lessons of Modigliani and Miller's theorem that there is no alchemy of finance and that without real assets it is not possible to create new value and enlarge the capital. With their capital structure irrelevance hypothesis, they accentuated the importance of the meaningful usage of capital and threats from a belief in financial illusions. 


\section{Journal of Contemporary Management Issues}

Contrary to the aforementioned, the traditional approach to capital structure, which is also known as the static trade-off theory, advocates the existence of an optimal capital structure i.e. the one that maximizes the market value of a company (Myers, 1984). Namely, up to a certain level, debt financing is welcomed, as positive effects of the tax shield, in case of recording profit, override negative effects of financial risk premium increase i.e. higher refinancing costs. The market value of a company is maximized to the point at which the net effect between positive and negative implications of a certain financial leverage usage is zero. Beyond that point, further debt financing increases the chance for company bankruptcy as well as refinancing risk, finally enlarging the weighted average cost of capital so that it diminishes a tax shield benefits if there is still some profit volume. Thus, the key implications of this theory for the business practice could be summarized in the following way: 1) there should be more active planning of capital structure, 2) costs and benefits of certain financing source should be taken into observation, and, finally, 3) going into debt should be moderate and prudent. In addition, companies with more stable cash flows will be able to bear higher indebtedness levels than riskier companies, ceteris paribus (Ryen et al., 1997, 42). Nevertheless, it might be difficult or even impossible to achieve an optimal capital structure at any point in time, due to required time and costs for adjustment as well as other objective limitations. In such a manner, Flannery and Rangan (2006) found that, in the 1965-2001 period, the US nonfinancial companies failed to bridge the gap between the current and target capital structure by closing merely $1 / 3$ of the gap in every observed year. Similarly, Berger et al. (2008) concluded that the large listed US bank holdings managed to close between $45 \%$ to $57 \%$ of the capital structure gap in the 1992-2006 period. Furthermore, the traditional approach to capital structure does not explain why companies with an increasing market value undertake equity, instead of debt financing. According to this theory, debt financing would move those companies closer to the optimal capital structure. The described case and similar inconsistencies of the static trade-off theory with a business practice were explained with the pecking order theory (Myers, 1984; Myers and Majluf, 1984). The pecking order theory is all about the hierarchy of financing sources, which is set and followed by managers to choose the least "painful" option at a certain moment, to be more precise, the one which causes the least resistance and the lowest level of market discipline. Thus, rather than having a target capital structure, there is a preferred order of financing in a company according to which internal sources have priority over external sources, debt is preferred over equity financing, whereas the dividend policy should be stable. Equity financing is advisable when company stocks are overvalued and business outcomes are expected to deteriorate. On the contrary, debt financing is preferred in case of market undervaluation and when strong business results are being anticipated. In such circumstances, the agency problem or the conflict of interests between the company's shareholders and managers is avoided. Later on, the original pecking order theory was modified with conclusions, derived from the corporate financial practice according to which there is an aversion towards both debt and equity financing (Myers, 1984). The risk of equity offering failures makes this source of financing the "last resort" for company managers, while heavy reliance on debt financing is also unwelcomed to sustain a desirable level of credit capacity and minimize the financial disorder threat. This is why some new explanations were introduced dealing more 
with the information asymmetries in financial decision-making as well as with agency problems between shareholders and debtholders and between shareholders and managers,

Agency problem appears whenever a certain level of cooperation is required for some goal achievement or when there is a necessity for activities such as risk-sharing and monitoring (Eisenhardt, 1989, 58-59). It implies a conflict of interests and initiatives between various parties in the process. Under-investment hypothesis and risk-shifting hypothesis are the two most common forms of agency problems between company owners and creditors and they are of crucial importance for the capital structure discussion. Under-investing or missing the profitable investments on purpose usually occurs if there is a poor level of equity financing of a company, as company shareholders or managers refuse to increase the equity financing of the company to prevent a potential sizeable transfer of financial results to company creditors (Frydenberg, 2004, 17-18). Moreover, managers of highly indebted companies, which are, thus, closer to bankruptcy, might minimize their efforts in launching and monitoring projects, as their position is less stable (Ryen et al., 1997, 43). Inversely, according to the risk-shifting or asset-substitution hypothesis, a high indebtedness level might increase the odds for the adoption of a riskier business strategy, as potential losses will be incurred mainly by the company debtholders, while potential profit will be distributed among its shareholders. Excessive dividends payout and additional financing with senior debt instruments are alternative ways of how company owners might achieve certain benefits, at the expense of creditors (Orgler and Taggart, 1981, 19; Frydenberg, $2004,17)$. Along with agency issues in shareholders - debtholders relation, there is a conflict of interest between the company's shareholders and managers. Concerning that, Berger et al. $(1995,399)$ conclude that on the lower level of equity financing there is an agency problem between company's shareholders and debtholders, while on the higher level of equity financing, agency problem between owners and creditors is diminishing, but the conflict of interests between owners and managers is growing. Excessive consumption and avoidance of going into debt due to the pressure of repayment that might result from it, are the two typical modes of managerial behavior which is more oriented towards building up managers' wealth and power, rather than towards adding value to the company and its shareholders (Ryen et al., 1997, 44). The aforementioned agency problem is well known in the literature as the agency costs hypothesis. According to the latter, higher indebtedness of company (due to the repayment obligation) reduces the managers' overall cost inefficiency (Berger and Bonaccorsi di Patti, 2006), as well as wastefulness of financial sources, hubris, and opportunistic behavior, which might appear if there is a significant free cash flow (Jensen and Meckling, 1976). The importance of the agency theory for solving the capital structure issues in the business of banking was acknowledged with the development of the moral hazard theory and the capital buffer theory. The aforementioned was the most convincing confirmation that the theory of capital structure, which originally emerged in the area of non-financial enterprises, is also applicable for the banking services industry, despite its numerous specificities and extensive regulatory requirements, oversight, and protection (i.e. via the deposit insurance system, the lender of last resort and other safety net elements).

According to the moral hazard theory (Koehn and Santomero, 1980; Kim and 


\section{Journal of Contemporary Management Issues}

Santomero, 1988; Gennotte and Pyle, 1991; Rochet, 1992; Blum, 1999), bank managers will endeavor to keep the bank capital at the required regulatory minimum, which is in line with the pecking order theory about equity financing as the last resort. Furthermore, due to a safety net presence (especially via the deposit insurance system), the market discipline of banks is rather modest (e.g. Hellmann et al., 2000), which directs bank managers to exploit the benefits of the financial leverage increase without any significant enlargement of the cost of capital. Thus, if regulators would request a bank capital build-up, based on the moral hazard theory conclusions, consequently higher costs of financing will be compensated with the asset riskiness elevation. Concerning that, on the data sample of 6,800 banks from the 13 OECD countries in the 1993-2007 period, King (2010) estimated an increase in the interest rate spread for 15 basis points, if an increase in the demanded regulatory capital ratio for $1 \%$ enlarges the cost of bank capital, ceteris paribus. Afterward, many appraisals confirmed prior conclusions about the positive impact of higher capital requirements on the cost of bank credit. However, estimations varied from merely 2 basis points to 80 basis points of an increase in the lending rates due to a more restrictive capital regulation (according to a compilation of studies by Cohen and Scatigna, 2014 and Dagher et al., 2016).

Thus, according to the moral hazard theory, any attempt by prudential authorities to demand additional capital will be dismissed as a counterproductive measure. Namely, if bank shareholders/managers would insist on scoring the earlier return on equity (or even increasing it), the possible ways to achieve that goal in the presence of capital regulation pressures are 1) to reduce operating costs (throughout economies of scale, economies of scope, x-efficiency, economies of synergy or more favorable debt financing), or/and 2) to increase the asset riskiness. However, the business practice revealed quite a different behavioral pattern than minimal compliance of banks with the capital requirements regulation. For instance, Berger et al. (2008) found out that even large or too-big-to-fail banks, which were listed on the US stock exchanges over the 1992-2006 period, maintained the bank capital levels significantly above the regulatory required minimum, and not as a consequence of the passive approach to bank capital management (i.e. by retaining earnings), but the active approach or equity offerings. Similarly, Gropp and Heider (2009) concluded that large and profitable banks in the US and the EU-15 in the period from 1991-2004, have sizeable surpluses of capital when compared to the regulatory requests although those banks could carry out equity issuance promptly and effortlessly if needed. On the other hand, Ashraf et al. (2016) disclosed global evidence (by observing 8700 banks from 58 countries in the period 1998-2007) concerning the positive impact of capital requirements on bank retained earnings. However, the effect of capital regulation on bank dividend payments limitation to meet the minimum regulatory capital requests was rather modest in the financial crisis period. Furthermore, the PriceWaterHouseCoopers $(2004,64)$ revealed results that even before a more restrictive capital regulation imposed by the Basel II accord, the average bank regulatory capital level in the EU-15 in the year 2002 was 3,8 percentage points higher than the regulatory required one $(8 \%)$. According to Berger and Bouwman (2009), a higher bank capital level might be of essential importance in times of financial crises, as they demonstrated that it increases the likelihood for bank survival and might be a source of its comparative advantage in retaining 
existing bank clients and attracting new ones. In addition, higher bank capitalization might improve bank profitability in a crisis period, following the evidence by Osborne et al. (2012) for the US banks. These are the reasons why the capital buffer theory or the precautionary regulatory capital theory (Marcus, 1984; Calem and Rob, 1999; Milne and Whalley, 2001; Milne, 2002) came under the spotlight. Contrary to the moral hazard theory, the capital buffer theory upholds the view about the prudent and cautious behavior of bank managers under the regulatory pressures as they endeavor to keep the surplus of capital above the minimally prescribed levels (i.e. have capital buffers or voluntary capital) and cherish such asset risk management policies which will not increase the odds for a bank failure.

To sum up, the debt financing has an advantage of the tax shield usage; it adds to management cost efficiency and is perceived to signal better company prosperity than equity financing, but it certainly increases the costs of financial distress and the likelihood of bankruptcy as well as the preferred risk level of shareholders (Wall and Peterson, 1998, 8). Furthermore, in the business of banking the issue of capital structure comes down to the point of the bank capital level, which is important as it impacts at least three areas (Diamond and Rajan, 2000):

1. liquidity creation and bank refinancing opportunities,

2. credit origination, the cost of capital and, consequently, the selection of bank clients, and finally,

3. bank safety and soundness as it protects the bank from unexpected losses and business shocks.

It will consequently influence the bank profitability. With that in mind, we seek to answer a question regarding the capital regulation effect on various bank profitability indicators which will capture repercussions of certain bank capital structure under capital requirements pressure for the overall bank profitability, as well as its shareholders and clients.

\section{CAPITAL REGULATION AS A KEY DRIVER OF BANKING INDUSTRY PROFITABILITY: A REVIEW OF THE
EMPIRICAL BACKGROUND}

In-depth analyses of the capital requirements influence on bank profitability are scarce in comparison to the sizeable body of literature on the determinants of bank profitability, especially when bank profitability is approximated with indicators, other than the return on assets. Thus, we review the articles which were the most important for our study, whereas the empirical background on the determinants of bank profitability is beyond the scope of this paper.

Naceur and Kandil (2009) took into observation 28 banks from Egypt in the period from 1989-2004 and confirmed a positive impact of equity to assets ratio on the return on assets (ROA) and net interest margin (NIM), while no impact of bank capitalization on the return on equity (ROE) was found. Thus, it was concluded that higher capital requirements through lower expected bankruptcy costs and consequently lower financing costs add to bank profitability approximated with ROA. However, higher costs of equity financing are transferred to bank clients, as the impact of capital regulation on the cost of banking intermediation (NIM) is positive. Finally, the insignificant influence of the financial structure on $\mathrm{ROE}$ is explainable by the zero net effect 


\section{Journal of Contemporary Management Issues}

between higher costs of equity financing and higher NIM. The aforementioned conclusions are valid only in the short run, while in the long run, the effects of capital requirements on bank profitability indicators tend to perish. In such a manner, de Bandt et al. (2018) pointed out the mandatory capital requirements insignificance for the bank ROA, when 25 French banks were taken into consideration in the period 2007-2014. However, the voluntary capital that banks held affected their profitability positively. On the other hand, some earlier results that covered 17 French banking groups in the period from 1993-2012 documented a positive impact of an aboveaverage increase in bank capital requirements to bank ROA and ROE (de Bandt et al., 2017). Next, Fungáčová and Poghosyan (2011) revealed the results for the Russian banking sector from 1999 to 2007 according to which, regardless of the ownership type, the equity to assets ratio adds to NIM. The same conclusion holds for the bank data sample from the European Union members and candidate countries, but only for the 1995-2000 period, which is characterized by the banking sector consolidation (Kasman et al., 2010). Namely, in the postconsolidation period i.e. from 2001-2006, due to increased competition, mainly the low capitalized banks entered higher risks which consequently raised their NIMs and the overall impact of equity to assets ratio on NIM was a negative one. On the other hand, based on the data for the Estonian banks in the period 1999-2011, Männasoo (2013) concluded that there is a positive impact of the capital adequacy ratio on interest margin.

Coccorese and Girardone (2017) documented a positive effect of capital requirements on ROA on the data sample composed of 4414 banks worldwide in the period from 2000-2013 and explained that higher profitability of better-capitalized banks is driven by their increased credit risk capacity, larger off-balance-sheet activities and more efficient cost management. Improved cost efficiency was also attributed to higher capital requirements of Chinese banks in domestic ownership in the period 2004-2009 (Pessarossi and Weill, 2015).

Furthermore, Bitar et al. (2016) analyzed the data set for 168 banks from the Middle East and North Africa region for the 1999-2013 time span. Again, a positive influence of regulatory capital on bank profitability was recorded. In addition, the authors emphasize the importance of a developed institutional framework for the bank risk management strategies, as in such countries, too-big-to-fail banks react to higher capital requirements by improving their risk management process and downsizing the credit risk, which consequently downsizes the agency costs and enlarges bank profitability. On the other hand, Boubakri et al. (2017) confirmed that even when national culture is taken into consideration, the bank equity to assets ratio drives ROE in a negative, and NIM in a positive way. However, in the banking crisis period, higher equity financing might enlarge ROE, regardless of the bank size, as was detected by Berger and Bouwman (2009) for more than 18300 US banks in the period from 1984-2008.

According to the results of the crosscountry study of 4555 banks in 51 countries in the period from 2000-2012, which were obtained by Tabak et al. (2017), the initial capitalization level is an important factor that drives bank profitability, measured with ROA, either positively or negatively. Namely, on a low capitalization level, capital buffers contribute to profitability buildup as they boost bank credit capacity, reduce costs of financing and make banks less 
vulnerable to credit contraction in the economic downturn. On the other hand, in the case of sizeable capital buffers, profitability is declining, as holding too much capital is inefficient. The latter was earlier confirmed by Osborne et al. (2012) who analyzed the data sample of US banks in the period from the late 1970s to the year 2010 and found that with an exemption of the crisis period, sizeable capital buffers decrease ROA.

To sum up, the mixed results of empirical studies concerning the impact of capital requirements on various bank profitability indicators, make it a rather important topic on the research agenda in the area of capital regulation and, consequently, banking stability.

\section{RESOLVING THE CAPITAL REGULATION AND BANK PROFITABILITY PUZZLE FOR CROATIA IN TIMES OF LOW ECONOMIC ACTIVITY}

\subsection{Data, methodology, and model development}

The empirical analysis of the capital regulation contribution to bank profitability was carried out on the data sample which was composed of 24 commercial banks from the Croatian banking sector in the period from 2011-2016. Only the banks which were operating continuously during the observed period were taken into consideration, while due to modest financial reporting (unavailability of online financial reports for a certain year) some of them were excluded from further investigation. Namely, based on financial reports which were disclosed by the sample banks on their official websites, we calculated financial indicators and other model variables. Attention was focused on a period of low overall economic activity (as in, e.g. Berger and Bouwman, 2009; Osborne et al., 2012; de Bandt et al., 2017; Tabak et al., 2017; de Bandt et al., 2018) to provide an assessment of the regulatory capital importance in times of poor credit growth and scarce profit opportunities. In such a manner, a conclusion about the importance of risk-weighted capital requirements for the bank's business performance, and consequently banking stability could be reached. Dynamic panel data methodology was suitable to solve this research problem empirically, to be more precise Blundell-Bond estimator was employed, due to a small number of periods ( 6 years) and groups ( 24 banks) characterizing the data sample, and rather high persistency of model variables.

The dependent variable - bank profitability, was measured with the return on assets (ROA), return on equity (ROE), and net interest margin (NIM). Capital regulation (bank solvency) was encompassed with the following financial indicators: 1) equity to assets ratio (CAP), 2) capital adequacy ratio (ADEQ), 3) tier 1 ratio (TIER1ADEQ), and 4) capital quality ratio (CAPQUAL). The list of control variables involved the asset liquidity ratio (LIQ), asset quality ratio (NPL), asset riskiness ratio (RWA), operating efficiency ratio (OPEFF), off-balance sheet variable (OBS), and one macroeconomic variable - real annual gross domestic product growth rate (GDPG). The list of independent variables is listed in Table 1. 


\section{Journal of Contemporary Management Issues}

Table 1. Independent variables

\begin{tabular}{|c|c|c|}
\hline Variable & Definition & Group of variables \\
\hline CAP & Equity / Total assets & Capital structure indicator \\
\hline ADEQ & $\begin{array}{l}\text { Capital adequacy ratio = Regulatory capital / } \\
\text { Risk-weighted assets }\end{array}$ & Regulatory capital ratio \\
\hline TIER1ADEQ & $\begin{array}{l}\text { Tier } 1 \text { ratio = Core equity capital / Risk } \\
\text { weighted assets }\end{array}$ & Regulatory capital ratio \\
\hline CAPQUAL & $\begin{array}{l}\text { Capital quality ratio = Core equity capital } / \\
\text { Total assets }\end{array}$ & Regulatory capital ratio \\
\hline LIQ & Liquid assets / Total assets & $\begin{array}{l}\text { Liquidity indicator - asset } \\
\text { liquidity indicator }\end{array}$ \\
\hline OPEFF & $\begin{array}{l}\text { Operating efficiency indicator = Overheads } / \\
\text { Total assets }\end{array}$ & $\begin{array}{l}\text { Indicator of cost management } \\
\text { efficiency }\end{array}$ \\
\hline NPL & Non-performing loans / Total loans & Asset quality indicator \\
\hline RWA & Risk-weighted assets / Total assets & Asset riskiness indicator \\
\hline OBS & Ln (volume of derivatives) & Off-balance sheet indicator \\
\hline GDPG & Real GDP growth rate (annual rate) & Macroeconomic indicator \\
\hline
\end{tabular}

Source: Authors.

Bearing in mind various profitability $(\mathrm{PROF}=\mathrm{ROA}, \mathrm{ROE}, \mathrm{NIM})$ and solvency (SOLV $=\mathrm{CAP}, \mathrm{ADEQ}$, TIER1ADEQ, CAPQUAL) indicators, which were used to calculate the potential pressure which capital requirements regulation puts on bank management and consequently on its profitability, we performed a comprehensive evaluation of the following baseline model:

$$
\begin{aligned}
\text { PROF }_{i t} & =\mu+\gamma \cdot \text { PROF }_{i, t-1}+\beta_{1} \cdot S O L V_{\mathrm{it} 1}+\beta_{2} \cdot L I Q_{\mathrm{it} 2}+\beta_{3} \cdot \mathrm{OPEFF}_{\mathrm{it} 3}+\beta_{4} \cdot N P L_{\mathrm{it} 4}+ \\
& +\beta_{5} \cdot R W A_{\mathrm{it} 5}+\beta_{6} \cdot O B S_{\mathrm{it} 6}+\beta_{7} \cdot G D P G_{\mathrm{it} 7}+\alpha_{i}+\varepsilon_{\mathrm{it}} ; i=1, \ldots N, t=1, \ldots T,
\end{aligned}
$$

where $i$ denotes an individual and $t$ denotes time, $\mu$ is an intercept, $\gamma$ is a parameter of the lagged dependent variable, $\beta_{l}, \beta_{2}, \ldots, \beta_{K}$ are the parameters of the exogenous variables, $\alpha_{i}$ is an individual-specific effect and $\varepsilon_{i t}$ are the error terms.

We assume a positive impact of solvency indicators on the ROA and NIM while expecting the negative one on the ROE to confirm the presumption that the riskweighted bank capital regulation affects bank shareholders (whose interests are approximated with the ROE) and stakeholders (whose interests are approximated with the ROA for bank managers and NIM for bank clients) differently. Namely, a higher solvency level enables a better pledge against the bank risks and allows further sustainable bank asset growth, and thus higher overall bank profitability measured via ROA is backed up with the lower financial risks and more prudent asset growth and risk management. In the nutshell, we adopt the conclusions of the capital buffer theory. Regarding ROE, we admit the endogeneity issue between various solvency 
indicators and ROE due to equity being a part of the ROE formula, as well as equity is composed of retained and current profit/ loss. Therefore, higher solvency might reduce the ROE, solely because of the ROE formula. However, if this methodological problem is successfully solved, a negative impact of higher bank solvency on the shareholders' profitability might reflect the case of both financial and business risks being downsized, which is again in line with the capital buffer theory. Finally, an increase in the bank solvency level might increase bank shareholders' profit requests, which could be achieved throughout a higher NIM level (see e.g. Naceur and Kandil, 2009) i.e. simultaneous interest income increase and interest expenses decrease, or solely through reducing the costs of financing as a consequence of lower financial risks of uninsured bank debtholders in case of higher bank capitalization (Berger and Mester, 1997). In line with that, capital requirements regulation might affect mostly bank clients, as all the direct regulatory costs are likely to be transferred to them, either throughout higher interest income, i.e. more expensive loans (as a consequence of higher proportion of expensive equity financing in the bank capital structure), and/or on the other hand insufficient loan approval.

Control variables were selected by following the standard empirical body of knowledge on the determinants of bank profitability, data availability criteria, as well as model limitations considering the number of explanatory variables. Asset liquidity (LIQ) is expected to be inversely related to bank profitability measured with ROA and ROE as lower yields are collected on more liquid assets. Concerning NIM, higher LIQ might increase it as bank managers could try to compensate for lower asset profitability by increasing the NIM.
Operating inefficiency (OPEFF) should lower ROA and ROE, while it might increase NIM. Namely, according to Dumičić and Ridzak (2013) lower operating efficiency could be compensated with the higher cost of banking intermediation (NIM) i.e. by transferring the burden of poor operating efficiency on bank clients through higher interest rates on loans, and lower interest rates on deposits. Similarly, lower asset quality (NPL) is expected to reduce ROA and ROE, which will endeavor to be compensated with higher risk premiums, which will consequently produce higher NIM (Diko, 2019). Furthermore, up to a certain level as well as up point in time, higher asset riskiness (RWA) will increase bank profitability (ROA and ROE) as riskier assets, primarily loans, bear higher interest income which increases the NIM (Witowschi and Luca, 2016). In addition, the higher the off-balance-sheet activities by banks, the higher ROA and ROE are expected, while the impact on NIM should be negative due to a trade-off between non-interest activities and traditional lending ones i.e. due to the diversification of bank income sources (Le, 2017). Finally, a more favorable macroeconomic surrounding (approximated with the GDPG indicator) should alter bank profitability, mainly due to a greater demand for loans (e.g. Witowschi and Luca, 2016).

\subsection{Research results}

The empirical results of the estimated panel models with ROA, ROE, and NIM as profitability indicators are given in Tables 2-4. Solvency indicators were interchangeably employed in the models, due to a strong correlation between each of them. Furthermore, lagged values of solvency variables in panel models, with ROE as the dependent variable, were used to solve a reverse causality problem. Namely, due to a small number of groups, those variables 


\section{Journal of Contemporary Management Issues}

could not be treated as endogenous ones. To sum up, we calculated the results for 12 panel data models in total. All calculations were made in statistical package STATA/ S.E. 13.1, as well as correlation matrix and descriptive statistics which are not appended to the article, due to its size restrictions, but are available upon request.

Firstly, econometric results confirm a certain profit persistency in the Croatian banking sector, regardless of the profitability indicator which was employed as the estimated parameters of the lagged dependent variables were always positive. However, when ROA and ROE were dependent variables, persistency was lower than in the NIM case. Namely, estimated coefficients in the ROA and ROE cases were not higher than 0.25 , while in the case of NIM they were almost 0.5. This indicates that banks' net interest margin is heavily dependable upon the achieved net interest margins in the previous year i.e. that the speed of adjustment of NIM to the banking sector trends is rather small, despite the fairly competitive Croatian banking industry when ROA and ROE coefficients value are taken into consideration.

Secondly, a positive impact of higher solvency on the ROA and NIM was detected, which is in line with the capital buffer theory and our assumption. This means that higher solvency adds to overall bank profitability throughout its positive impact on the NIM i.e. simultaneous increase in the interest income (due to enlarged growth opportunities and business risks), and decrease in the interest expenses or solely reduction in the interest expenses due to lower financial risks. The opposite conclusions are reached if bank solvency and profitability are simultaneously decreasing. To be more precise, if bank solvency is decreasing, financial risks and interest expenses are increasing, which, in turn, downsizes NIM and, consequently, ROA, which is simultaneously affected by higher growth restrictions. In addition to that, higher solvency reduces shareholders' profitability measured with the ROE, which might turn them towards riskier asset selection followed by higher interest income and later on higher ROA. Thus, our results confirm that the capital requirements regulation impairs shareholders' profitability (ROE) and directs bank managers towards seeking more profitable (riskier) assets and/ or transferring the regulatory costs on bank clients (NIM) to preserve the overall bank profitability (ROA). Obtained results were consistent regardless of the type of solvency indicator being employed to depict capital requirements regulation. They are also comparable to the findings of the majority of studies reviewed in the previous section. Thus, having larger equity financing and capital requirements might be beneficial for bank profitability, especially in times of poor macroeconomic performance when bank financial results are weak and business risks enlarged, while, at the same time, larger regulatory pressures being imposed on banks to preserve banking sector stability. In such circumstances, having sufficient surplus in bank regulatory capital makes a difference between banks that successfully cope with the crisis and those which struggle for their existence, due to lower financial, and, consequently, business risks as well as more relaxed position regarding the additional regulatory burden of the first ones. 
Table 2. Panel data estimations of the baseline model with ROA as a dependent variable

\begin{tabular}{|c|c|c|c|c|}
\hline \multirow{2}{*}{$\begin{array}{l}\text { Explanatory variable } \\
\operatorname{ROA}_{\mathrm{i},-\mathrm{t}-1}\end{array}$} & \multicolumn{4}{|c|}{ Baseline model } \\
\hline & $\begin{array}{l}-0,0018 \\
(0,0177)\end{array}$ & $\begin{array}{l}0,0665^{* * *} \\
(0,0242)\end{array}$ & $\begin{array}{l}0,0535^{* *} \\
(0,0247)\end{array}$ & $\begin{array}{l}0,0199 \\
(0,0219)\end{array}$ \\
\hline $\mathrm{CAP}_{\mathrm{i}, \mathrm{t}}$ & $\begin{array}{l}0,2201^{* * *} \\
(0,0087) \\
\end{array}$ & - & - & - \\
\hline $\mathrm{ADEQ}_{\mathrm{i}, \mathrm{t}}$ & - & $\begin{array}{l}0,1206^{* * *} \\
(0,0083)\end{array}$ & - & - \\
\hline TIER1ADEQ ${ }_{i, t}$ & - & - & $\begin{array}{l}0,1682^{* * *} \\
(0,0102)\end{array}$ & - \\
\hline CAPQUAL $_{\mathrm{i}, \mathrm{t}}$ & - & - & - & $\begin{array}{l}0,2186^{* * *} \\
(0,0108)\end{array}$ \\
\hline $\mathrm{LIQ}_{\mathrm{i}, \mathrm{t}}$ & $\begin{array}{l}0,0569^{* * *} \\
(0,0110)\end{array}$ & $\begin{array}{l}0,0498^{* * *} \\
(0,0146)\end{array}$ & $\begin{array}{l}0,0492^{* * *} \\
(0,0096)\end{array}$ & $\begin{array}{l}0,0608^{* * *} \\
(0,0112)\end{array}$ \\
\hline $\mathrm{OPEFF}_{\mathrm{i}, \mathrm{t}}$ & $\begin{array}{l}-1,0715^{* * *} \\
(0,0324)\end{array}$ & $\begin{array}{l}-0,9339^{* * *} \\
(0,0460)\end{array}$ & $\begin{array}{l}-0,9602^{* * *} \\
(0,0447)\end{array}$ & $\begin{array}{l}-1,0263^{* * *} \\
(0,0338)\end{array}$ \\
\hline $\mathrm{NPL}_{\mathrm{i}, \mathrm{t}}$ & $\begin{array}{l}-0,4380^{* * *} \\
(0,0087)\end{array}$ & $\begin{array}{l}-0,4536^{* * *} \\
(0,0106)\end{array}$ & $\begin{array}{l}-0,4415^{* * *} \\
(0,0086)\end{array}$ & $\begin{array}{l}-0,4350^{* * *} \\
(0,0110)\end{array}$ \\
\hline $\mathrm{RWA}_{\mathrm{i}, \mathrm{t}}$ & $\begin{array}{l}0,0148^{* *} \\
(0,0066)\end{array}$ & $\begin{array}{l}0,0304^{* * *} \\
(0,0088)\end{array}$ & $\begin{array}{l}0,0402^{* * *} \\
(0,0083)\end{array}$ & $\begin{array}{l}0,0075 \\
(0,0074)\end{array}$ \\
\hline $\mathrm{OBS}_{\mathrm{i}, \mathrm{t}}$ & $\begin{array}{l}-0,0002^{* *} \\
(0,0001) \\
\end{array}$ & $\begin{array}{l}-0,0003^{*} \\
(0,0001) \\
\end{array}$ & $\begin{array}{l}-0,0001^{*} \\
(0,0001)\end{array}$ & $\begin{array}{l}-0,0001 \\
(0,0001)\end{array}$ \\
\hline $\mathrm{GDPG}_{\mathrm{i}, \mathrm{t}}$ & $\begin{array}{l}0,0308 \\
(0,0301)\end{array}$ & $\begin{array}{l}0,0126 \\
(0,0322)\end{array}$ & $\begin{array}{l}0,0401 \\
(0,0322)\end{array}$ & $\begin{array}{l}0,0264 \\
(0,0239)\end{array}$ \\
\hline$\alpha$ & $\begin{array}{l}-0,0081 \\
(0,0059)\end{array}$ & $\begin{array}{l}-0,0157^{* *} \\
(0,0079)\end{array}$ & $\begin{array}{l}-0,0283^{* * *} \\
(0,0078)\end{array}$ & $\begin{array}{l}-0,0035 \\
(0,0067)\end{array}$ \\
\hline Number of observations & 119 & 119 & 119 & 119 \\
\hline Number of banks & 24 & 24 & 24 & 24 \\
\hline Sargan test ( $\mathrm{p}$ - value) & 0,2517 & 0,4122 & 0,4070 & 0,2898 \\
\hline $\begin{array}{l}\text { First-order autocorrelation } \\
(\mathrm{p}-\text { value })\end{array}$ & 0,2380 & 0,2652 & 0,2310 & 0,2340 \\
\hline $\begin{array}{l}\text { Second-order autocorrelation } \\
\text { (p-value) }\end{array}$ & 0,7616 & 0,6073 & 0,2004 & 0,1655 \\
\hline
\end{tabular}

${ }^{* * *}$ Statistically significant at $1 \%$ level, ${ }^{* *}$ Statistically significant at $5 \%$ level, ${ }^{*}$ Statistically significant at $10 \%$ level.

Source: Authors' calculation.

Most of the other empirical results were in line with the expectations. Thus, a higher operating efficiency indicator (OPEFF) has a positive impact on bank NIM, and negative on bank ROA, which means that banks operating inefficiency is achieved at the expense of bank clients i.e. it enlarges the cost of banking intermediation (NIM), but still insufficiently to sustain overall bank profitability (ROA). Similarly, an increase 


\section{Journal of Contemporary Management Issues}

of the non-performing loans (NPL) reduces the banks' ROA and ROE, which is logical, when the income statement structure is in mind as well the NPLs' effect on the asset shrinkage. Contrary to that, NPLs are followed by the NIM increase, due to asset shrinkage as well as due to endeavors to compensate lower profitability with a net interest income increase. Furthermore, a positive linkage between asset riskiness (RWA) and profitability (ROA and ROE) is recorded as well as a favorable impact of GDP growth on the NIM (and partly ROE). Finally, only for LIQ and OBS, we obtained somewhat unexpected results. Thus, having more liquid assets (LIQ) turns out to increase the banks' ROA and ROE and to decrease their NIM, while higher off-balance-sheet activity (OBS) decreases the banks' ROA and ROE. The latter might indicate insufficient knowledge and experience of bank managers when using financial derivatives which are the cornerstone of the off-balance sheet business or the unfavorable derivatives market conditions. On the other hand, a positive impact of bank liquidity on ROA and ROE, and a negative impact on NIM might be explained with the practice of charging off the loans which are unlikely to be collected, better complying with the more restrictive liquidity requirements, and/or signal a slowdown in credit growth on a certain market. In that case, lower NIM would be compensated with the higher non-interest income activity to increase the overall bank profitability.

Table 3. Panel data estimations of the baseline model with ROE as a dependent variable

\begin{tabular}{|c|c|c|c|c|}
\hline \multirow{2}{*}{$\begin{array}{l}\text { Explanatory variable } \\
\operatorname{ROE}_{\mathrm{i},-1}\end{array}$} & \multicolumn{4}{|c|}{ Baseline model } \\
\hline & $\begin{array}{l}0,187 \\
7^{* * *} \\
(0,0370)\end{array}$ & $\begin{array}{l}0,1619^{* * *} \\
(0,0295)\end{array}$ & $\begin{array}{l}0,2497^{* * *} \\
(0,0339)\end{array}$ & $\begin{array}{l}0,2062^{* * *} \\
(0,0267)\end{array}$ \\
\hline $\mathrm{CAP}_{\mathrm{i}, \mathrm{t}-\mathrm{I}}$ & $\begin{array}{l}-3,0139^{* * *} \\
(0,5914)\end{array}$ & - & - & - \\
\hline $\mathrm{ADEQ}_{\mathrm{i},-1-1}$ & - & $\begin{array}{l}-0,5428^{* *} \\
(0,2452)\end{array}$ & - & - \\
\hline TIER1ADEQ $_{\mathrm{i}, \mathrm{t}-1}$ & - & - & $\begin{array}{l}-2,5174^{* * *} \\
(0,4389)\end{array}$ & - \\
\hline CAPQUAL $_{\mathrm{i}, \mathrm{t}-1}$ & - & - & - & $\begin{array}{l}-3,1492^{* * *} \\
(0,4707)\end{array}$ \\
\hline $\mathrm{LIQ}_{\mathrm{i}, \mathrm{t}}$ & $\begin{array}{l}1,0091^{* *} \\
(0,4815)\end{array}$ & $\begin{array}{l}1,6515^{* * *} \\
(0,2452)\end{array}$ & $\begin{array}{l}1,2746^{* *} \\
(0,6211)\end{array}$ & $\begin{array}{l}1,3065^{* * *} \\
(0,4700)\end{array}$ \\
\hline $\mathrm{OPEFF}_{\mathrm{i}, \mathrm{t}}$ & $\begin{array}{l}-0,8645 \\
(1,7324)\end{array}$ & $\begin{array}{l}1,5466 \\
(1,5742)\end{array}$ & $\begin{array}{l}1,5976 \\
(1,9005)\end{array}$ & $\begin{array}{l}-0,6187 \\
(1,6369)\end{array}$ \\
\hline $\mathrm{NPL}_{\mathrm{i}, \mathrm{t}}$ & $\begin{array}{l}-6,7846^{* * *} \\
(0,6829) \\
\end{array}$ & $\begin{array}{l}-7,8786^{* * *} \\
(0,5940)\end{array}$ & $\begin{array}{l}-7,5312^{* * *} \\
(0,7625) \\
\end{array}$ & $\begin{array}{l}-7,1349^{* * *} \\
(0,6216)\end{array}$ \\
\hline $\mathrm{RWA}_{\mathrm{i}, \mathrm{t}}$ & $\begin{array}{l}0,3421^{* * *} \\
(0,0669)\end{array}$ & $\begin{array}{l}0,4004^{* * *} \\
(0,0989)\end{array}$ & $\begin{array}{l}0,3833^{* * *} \\
(0,0864)\end{array}$ & $\begin{array}{l}0,2673^{* * *} \\
(0,0426)\end{array}$ \\
\hline $\mathrm{OBS}_{\mathrm{i}, \mathrm{t}}$ & $\begin{array}{l}-0,0136^{* * *} \\
(0,0007)\end{array}$ & $\begin{array}{l}-0,0123^{* * *} \\
(0,0005)\end{array}$ & $\begin{array}{l}-0,0106^{* * *} \\
(0,0017)\end{array}$ & $\begin{array}{l}-0,0132^{* * *} \\
(0,0006)\end{array}$ \\
\hline $\mathrm{GDPG}_{\mathrm{i}, \mathrm{t}}$ & $\begin{array}{l}0,2715 \\
(0,5979)\end{array}$ & $\begin{array}{l}1,4167^{* *} \\
(0,5574)\end{array}$ & $\begin{array}{l}1,1651^{*} \\
(0,6201)\end{array}$ & $\begin{array}{l}-0,3046 \\
(0,5654)\end{array}$ \\
\hline
\end{tabular}


Management, Vol. 26, 2021, Special Issue, pp. 17-43

A. Kundid Novokmet, A. Pavić: CROATIAN BANKS PROFITABILITY UNDER CAPITAL ...

\begin{tabular}{|l|l|l|l|l|}
\hline$\alpha$ & $\begin{array}{l}0,2048^{* * *} \\
(0,0682)\end{array}$ & $\begin{array}{l}-0,256^{* * *} \\
(0,0992)\end{array}$ & $\begin{array}{l}0,1076 \\
(0,0898)\end{array}$ & $\begin{array}{l}0,1935^{* *} \\
(0,0767)\end{array}$ \\
\hline Number of observations & 115 & 115 & 115 & 115 \\
\hline Number of banks & 24 & 24 & 24 & 24 \\
\hline Sargan test (p- value) & 0,6436 & 0,2905 & 0,6154 & 0,5304 \\
\hline $\begin{array}{l}\text { First-order autocorrelation } \\
(\mathrm{p}-\text { value) }\end{array}$ & 0,1138 & 0,0633 & 0,0921 & 0,1183 \\
\hline $\begin{array}{l}\text { Second-order autocorrelation } \\
(\mathrm{p}-\text { value) }\end{array}$ & 0,1650 & 0,0911 & 0,1480 & 0,2131 \\
\hline
\end{tabular}

Statistically significant at $1 \%$ level, ${ }^{* *}$ Statistically significant at $5 \%$ level, ${ }^{*}$ Statistically significant at $10 \%$ level.

Source: Authors' calculation.

Table 4. Panel data estimations of the baseline model with NIM as a dependent variable

\begin{tabular}{|c|c|c|c|c|}
\hline \multirow{2}{*}{$\frac{\text { Explanatory variable }}{\mathrm{NIM}_{\mathrm{i}, \mathrm{-1}}}$} & \multicolumn{4}{|c|}{ Baseline model } \\
\hline & $\begin{array}{l}0,4853^{* * *} \\
(0,0750)\end{array}$ & $\begin{array}{l}0,4406^{* * *} \\
(0,0851)\end{array}$ & $\begin{array}{l}0,4565^{* * *} \\
(0,0729)\end{array}$ & $\begin{array}{l}0,4912^{* * *} \\
(0,0778)\end{array}$ \\
\hline $\mathrm{CAP}_{\mathrm{i}, \mathrm{t}}$ & $\begin{array}{l}0,0311^{* * *} \\
(0,0052)\end{array}$ & - & - & - \\
\hline $\mathrm{ADEQ}_{\mathrm{i}, \mathrm{t}}$ & - & $\begin{array}{l}0,0230^{* * *} \\
(0,0044)\end{array}$ & - & - \\
\hline TIER1ADEQ $_{i, t}$ & - & - & $\begin{array}{l}0,0241^{* * *} \\
(0,0051)\end{array}$ & - \\
\hline CAPQUAL $_{\mathrm{i}, \mathrm{t}}$ & - & - & - & $\begin{array}{l}0,0304^{* * *} \\
(0,0057)\end{array}$ \\
\hline $\mathrm{LIQ}_{\mathrm{i}, \mathrm{t}}$ & $\begin{array}{l}-0,0220^{* * *} \\
(0,0072)\end{array}$ & $\begin{array}{l}-0,0174^{* *} \\
(0,0084)\end{array}$ & $\begin{array}{l}-0,0201^{* * *} \\
(0,0070)\end{array}$ & $\begin{array}{l}-0,0210^{* * *} \\
(0,0076)\end{array}$ \\
\hline $\mathrm{OPEFF}_{\mathrm{i}, \mathrm{t}}$ & $\begin{array}{l}0,0809^{* * *} \\
(0,0212)\end{array}$ & $\begin{array}{l}0,0814^{* * *} \\
(0,0244)\end{array}$ & $\begin{array}{l}0,0739^{* * *} \\
(0,0221)\end{array}$ & $\begin{array}{l}0,0852^{* * *} \\
(0,0226)\end{array}$ \\
\hline $\mathrm{NPL}_{\mathrm{i}, \mathrm{t}}$ & \begin{tabular}{|l|}
$0,0349^{* * *}$ \\
$(0,0054)$ \\
\end{tabular} & \begin{tabular}{|l}
$0,0342^{* * *}$ \\
$(0,0066)$ \\
\end{tabular} & \begin{tabular}{|l|}
$0,0342^{* * *}$ \\
$(0,0062)$ \\
\end{tabular} & $\begin{array}{l}0,0344^{* * *} \\
(0,0055) \\
\end{array}$ \\
\hline $\mathrm{RWA}_{\mathrm{i}, \mathrm{t}}$ & $\begin{array}{l}-0,0046 \\
(0,0065)\end{array}$ & $\begin{array}{l}0,0030 \\
(0,0076)\end{array}$ & $\begin{array}{l}0,0013 \\
(0,0069)\end{array}$ & $\begin{array}{l}-0,0049 \\
(0,0066)\end{array}$ \\
\hline $\mathrm{OBS}_{\mathrm{i}, \mathrm{t}}$ & $\begin{array}{l}0,0000 \\
(0,0000)\end{array}$ & $\begin{array}{l}0,0000^{*} \\
(0,0000)\end{array}$ & $\begin{array}{l}0,0000 \\
(0,0000)\end{array}$ & $\begin{array}{l}0,0000 \\
(0,0000)\end{array}$ \\
\hline $\mathrm{GDPG}_{\mathrm{i}, \mathrm{t}}$ & \begin{tabular}{|l|}
$0,0458^{* * *}$ \\
$(0,0058)$
\end{tabular} & $\begin{array}{l}0,0442^{* * *} \\
(0,0077)\end{array}$ & $\begin{array}{l}0,0462^{* * *} \\
(0,0072)\end{array}$ & $\begin{array}{l}0,0473^{* * *} \\
(0,0060)\end{array}$ \\
\hline$\alpha$ & \begin{tabular}{|l}
$0,0117^{* * *}$ \\
$(0,0045)$ \\
\end{tabular} & $\begin{array}{l}0,0062 \\
(0,0057) \\
\end{array}$ & \begin{tabular}{|l}
0,0077 \\
$(0,0049)$ \\
\end{tabular} & $\begin{array}{l}0,0118^{* *} \\
(0,0046)\end{array}$ \\
\hline Number of observations & 119 & 119 & 119 & 119 \\
\hline
\end{tabular}




\section{Journal of Contemporary Management Issues}

\begin{tabular}{|l|l|l|l|l|}
\hline Number of banks & 24 & 24 & 24 & 24 \\
\hline Sargan test (p-value) & 0,3085 & 0,3082 & 0,2630 & 0,3230 \\
\hline $\begin{array}{l}\text { First-order autocorrelation } \\
(\mathrm{p}-\text { value })\end{array}$ & 0,0139 & 0,0147 & 0,0167 & 0,0123 \\
\hline $\begin{array}{l}\text { Second-order autocorrelation } \\
(\mathrm{p}-\text { value })\end{array}$ & 0,4079 & 0,3426 & 0,3716 & 0,3847 \\
\hline
\end{tabular}

Statistically significant at $1 \%$ level, ${ }^{* *}$ Statistically significant at $5 \%$ level, ${ }^{*}$ Statistically significant at $10 \%$ level.

Source: Authors' calculation.

To support some of our assumptions as well as conclusions on the capital regulation impact on bank profitability, we have tested several channels throughout which bank capital requirements regulation might alter bank profitability. To be more precise, with a stronghold in Coccorese and Girardone (2017) we have tested the credit risk channel, off-balance-sheet channel, and operating efficiency channel of the capital regulation on bank profitability. Interaction variables between credit risk and capital regulation (RWACAP, RWAADEQ, RWATIER1ADEQ, and RWACAPQUAL), off-balance-sheet activity and capital regulation (OBSCAP, OBSADEQ, OBSTIER1ADEQ, and OBSCAPQUAL), and operating efficiency and capital regulation (OPEFFCAP, OPEFFADEQ, OPEFFTIER1ADEQ, and OPEFFCAPQUAL) were constructed and introduced in the baseline models with ROA, ROE, and NIM as dependent variables. As expected, we excluded solvency variables (CAP, ADEQ, TIER1ADEQ, and CAPQUAL) from the models as those variables are now encompassed with the interaction variables. With the similar argumentation of resolving the collinearity problem, we excluded RWA, OBS, and OPEFF from the models in which we particularly tested credit risk channel, off-balance-sheet channel, and operating efficiency channel of the

capital regulation. The empirical results of the estimated panel models with ROA, ROE, and NIM as profitability indicators and credit risk, off-balance-sheet, and operating efficiency channels effects of the capital regulation are disclosed in the appendix.

Following the aforementioned results, it can be concluded that the capital requirements regulation adds to banks return on assets throughout credit risk channel, off-balance-sheet channel, and operating efficiency channel, which means that higher levels of bank solvency increase its risk-weighted assets, off-balance-sheet activities, and operating inefficiency, which consequently results in higher ROA. Regarding the NIM models, there lacks solid empirical evidence of the off-balance sheet channel of capital regulation, but there is proof of the positive impact of capital regulation throughout the credit risk channel and operating efficiency channel on the bank net interest margin. To be more precise, when a bank's regulatory capital increases, a riskier asset choice as well as increased operating inefficiency will add to the bank's net interest margin, probably due to interest income growth and interest expenses reduction. Finally, there is a negative impact of the higher solvency levels on the ROE, which is achieved throughout all tested channels of the capital regulation impact, whereas the greatest effect is 
recorded for the operating efficiency channel of capital regulation. Thus, higher solvency levels in the previous year will decrease bank ROE in the following year by increasing the credit risk, off-balance-sheet activity, as well as by enlarging the operating inefficiency.

Overall, a more restrictive capital requirements regulation will decrease the shareholders' wealth, as well as damage the position of bank clients who will bear the burden of increased operating inefficiency, but it will improve overall bank profitability measured with the return on assets.

\section{CONCLUSION}

In the early stage of the capital requirements implementation, many attempts were made to discredit this regulatory concept. Therefore, for several years, the moral hazard theory of capital regulation dominated academic literature in the field of banking and finance. The main premise of the aforementioned theory is that higher solvency levels will have unintended effects on bank behavior, as under capital requirements pressures the bank profitability will start to melt down which might push the bank shareholders and managers towards accepting higher asset risks and outsourcing increased costs of financing and other regulatory costs on bank clients. That is why it was assumed that banks will maintain their regulatory capital on the lowest permitted levels. However, it turned out that banks voluntarily keep sizeable capital buffers i.e. the surplus of capital above the regulatory requirements, and a new explanation of such behavior appeared in the form of the capital buffer theory. With regards to the latter one, banks voluntarily keep capital buffers, so that they would have the ability for further asset growth and/or asset riskiness increase. Thus, higher capital buffers might consequently lead to even higher overall bank profitability. Having in mind all of those controversies as well as the existence of the empirical gap for the Croatian banking sector, we have performed an extensive analysis of the capital requirements impact on various components of bank profitability.

Our main findings support the assumption that capital requirements regulation might have a heterogeneous impact on bank shareholders and stakeholders. It turned out that higher solvency levels increase overall bank profitability measured with the return on assets as well as the net interest margin, which is a primary source of bank profitability in the traditional (commercial) banking model. On the other hand, shareholders' wealth approximated with the return on equity diminishes with the higher solvency levels. Furthermore, the burden of capital requirements also lands on bank clients (approximated with the net interest income) from whom a higher interest income could be charged and collected and/or lower deposit interest rate offered. However, if banks would manage their overheads in a more cost-efficient way, regulatory costs could be internalized, and not outsourced to bank clients. Finally, bank managers will increase asset riskiness and off-balance sheet business as a consequence of higher solvency levels and achieve higher overall profitability measured with the return on assets. This should not be perceived as imprudent behavior, as banks create their capital buffers with the final goal of using them to support the growth and approval of loans with higher risk weights.

Overall, the key message of this paper is that there is a trade-off between shareholders' profitability and banking stability, while the burden of regulatory costs is often 


\section{Journal of Contemporary Management Issues}

borne by bank clients, instead of being internalized with a more cost-efficient business of banking. Thus, the main conclusion of this research is that operating efficiency needs to be increased in the Croatian banking sector to avoid negative side-effects of capital requirements regulation on bank clients. However, more research in the area of banking cost efficiency as well as in the field of other implications of capital requirements regulation needs to be done to reach less general policy recommendations from the bank managers as well as prudential authorities' point of view.

\section{REFERENCES}

1. Ashraf, B. N., Bibi, B. and Zheng, C. (2016): How to Regulate Bank Dividends? Is Capital Regulation an Answer?, Economic Modelling, 57, 281-293.

2. Benston, G. J. (2007): Basel II and Bankers' Propensity to Take or Avoid Excessive Risk, Atlantic Economic Journal, 35 (4), 373-382.

3. Berger, A. N., Herring, R. J. and Szegö, G. P. (1995): The Role of Capital in Financial Institutions, Journal of Banking and Finance, 19 (3-4), 393-430.

4. Berger, A. N. and Mester, L. J. (1997): Inside the Black Box: What Explains Differences in the Efficiencies of Financial Institutions?, Journal of Banking and Finance, 21 (7), 895-947.

5. Berger, A. N. and Bonaccorsi di Patti, E. (2006): Capital Structure and Firm Performance: A New Approach to Testing Agency Theory and an Application to the Banking Industry, Journal of Banking and Finance, 30 (4), 1065-1102.

6. Berger, A. N., DeYoung, R., Flannery, M. J., Lee, D. and Öztekin, Ö. (2008): How Do Large Banking Organizations
Manage Their Capital Ratios? Journal of Financial Services Research, 34 (2-3), 123-149.

7. Berger, A. N. and Bouwman, C. H. S. (2009): Bank Capital, Survival, and Performance around Financial Crises. (Online: http://web.mit.edu/cbouwman/www/downloads/BergerBouwman BankCapPerfFinCrises.pdf)

8. Bitar, M., Saad, W. and Benlemlih, M. (2016): Bank Risk and Performance in the MENA Region: The Importance of Capital Requirements, Economic Systems, 40 (3), 398-421.

9. Blum, J. (1999): Do Capital Adequacy Requirements Reduce Risks in Banking?, Journal of Banking and Finance, 23 (5), 755-771.

10. Boubakri, N., Mirzaei, A. and Samet, A. (2017): National Culture and Bank Performance: Evidence from the Recent Financial Crisis, Journal of Financial Stability, 19, 36-56.

11. Calem, P. and Rob, R. (1999): The Impact of Capital-Based Regulation on Bank Risk-Taking, Journal of Financial Intermediation, 8 (4), 317-352.

12. Coccorese, P. and Girardone, C. (2017): Bank Capital and Profitability: Evidence from a Global Sample, Essex Finance Centre Working Papers, No. 19480 (Online: http://repository.essex. ac.uk/19480/1/17_Bank\%20capital\%20 and $\% 20$ profitability_cover.pdf)

13. Cohen, B. H. and Scatigna, M. (2014): Banks and Capital Requirements: Channels of Adjustment, Bank for International Settlements, Working Paper, No. 443, March.

14. Dagher, J., Dell'Ariccia, G., Laeven, L., Ratnovski, L. and Tong, H. (2016): Benefits and Costs of Bank Capital, International Monetary Fund, Staff Discussion Note, No. 16/04, March. 
15. Daníelsson, J., Embrechts, P., Goodhart, C., Keating, C., Muennich, F., Renault, O. and Song Shin, H. (2001): An Academic Response to Basel II, Special Paper, London School of Economics Financial Markets Group and Economic and Social Research Council Research Centre, No. 130, May.

16. de Bandt, O., Camara, B., Pessarossi, P. and Rose, M. (2017): Can Better Capitalised Banks be More Profitable? An Analysis of Large French Banking Groups Before and After the Financial Crisis, Economie et Statistique / Economics and Statistics, 494-495-496, 131-148.

17. de Bandt, O., Camara, B., Maitre, A. and Pessarossi, P. (2018): Optimal Capital, Regulatory Requirements and Bank Performance in Times of Crisis: Evidence from France, Journal of Financial Stability, 39, 175-186.

18. Diamond, D. W. and Rajan, R. G. (2000): A Theory of Bank Capital, The Journal of Finance, 55 (6), 2431-2465.

19. Diko, A. (2019): Determinants of Net Interest Margins in Turkish Banking System: A Panel Data Analysis, Maliye ve Finans Yazılar, 111, 233-266.

20. Dumičić, M. and Ridzak, T. (2013): Determinants of Banks' Net Interest Margins in Central and Eastern Europe, Financial Theory and Practice, 37 (1), 1-30.

21. Eisenhardt, K. M. (1989): Agency Theory: An Assessment and Review, Academy of Management Review, 14 (1), 57-74.

22. Flannery, M. J. and Rangan, K. P. (2006): Partial Adjustment toward Target Capital Structures, Journal of Financial Economics, 79 (3), 469-506.
23. Frydenberg, S. (2004): Theory of Capital Structure - A Review (Online: http://ssrn. com/abstract $=556631$ )

24. Fungáčová, Z. and Poghosyan, T. (2011): Determinants of Bank Interest Margins in Russia: Does Bank Ownership Matter?, Economic Systems, 35 (4), 481-495.

25. Gennotte, G. and Pyle, D. (1991): Capital Controls and Bank Risk, Journal of Banking and Finance, 15 (4-5), 805-824.

26. Gropp, R. and Heider, F. (2009): The Determinants of Bank Capital Structure, European Central Bank, Working Paper Series, No. 1096, September.

27. Hellmann, T. F., Murdock, K. C. and Stiglitz, J. E. (2000): Liberalization, Moral Hazard in Banking, and Prudential Regulation: Are Capital Requirements Enough?, American Economic Review, 90 (1), 147-165.

28. Jensen, M. C. and Meckling, W. H. (1976): Theory of the Firm: Managerial Behavior, Agency Costs and Ownership Structure, Journal of Financial Economics, 3 (4), 305-360.

29. Kasman, A., Tunc, G., Vardar, G. and Okan, B. (2010): Consolidation and Commercial Bank Net Interest Margins: Evidence from the Old and New European Union Members and Candidate Countries, Economic Modelling, 27 (3), 648-655.

30. Kim, D. and Santomero, A. M. (1988): Risk in Banking and Capital Regulation, The Journal of Finance, 43 (5), 1219-1233.

31. King, M. R. (2010): Mapping Capital and Liquidity Requirements to Bank Lending Spreads, Bank for International Settlements, Working paper, No. 324, November.

32. Koehn, M. and Santomero, A. M. (1980): Regulation of Bank Capital and Portfolio 


\section{Journal of Contemporary Management Issues}

Risk, The Journal of Finance, 35 (5), 1235-1244.

33. Kundid, A. (2012): How Much is the Choice of Capital Structure Important for Bank Profitability in Croatia?, Zagreb International Review of Economics and Business, 15, Special Conference Issue, 53-68.

34. Kundid, A. (2014): Heterogeneous Funding Patterns and Income Structure of Croatian Banks: Panel Data Evidence, Theoretical and Applied Economics, 21 (9), 23-42.

35. Le, T. D. (2017): The Interrelationship Between Net Interest Margin and NonInterest Income: Evidence from Vietnam, International Journal of Managerial Finance, 13 (5), 521-540.

36. Marcus, A. J. (1984): Deregulation and Bank Financial Policy, Journal of Banking and Finance, 8 (4), 557-565.

37. Männasoo, K. (2013): Determinants of Bank Interest Spreads in Estonia, Eastern European Economics, 51 (1), 36-60.

38. Miller, M. H. (1988): The Modigliani Miller Propositions After Thirty Years, Journal of Economic Perspectives, 2 (4), $99-120$.

39. Milne, A. (2002): Bank Capital Regulation as an Incentive Mechanism: Implications for Portfolio Choice, Journal of Banking and Finance, 26 (1), $1-23$.

40. Milne, A. and Whalley, A. E. (2001): Bank Capital Regulation and Incentives for Risk-Taking, Cass Business School Research Paper, December. (Online: http://papers.ssrn.com/sol3/papers. cfm?abstract_id=299319)

41. Modigliani, F. and Miller, M. H. (1958): The Cost of Capital, Corporation Finance and the Theory of Investment, American Economic Review, 48 (3), 261 - 297.
42. Moosa, I. A. (2010): Basel II as a Casualty of the Global Financial Crisis, Journal of Banking Regulation, 11 (2), 95-114.

43. Myers, S. C. (1984): The Capital Structure Puzzle, Journal of Finance, 39 (3), $575-592$.

44. Myers, S. C. and Majluf, N. S. (1984): Corporate Financing and Investment Decisions When Firms Have Information That Investors Do Not Have, Journal of Financial Economics, 13 (2), 187-221.

45. Naceur, S. B. and Kandil, M. (2009): The Impact of Capital Requirements on Banks' Cost of Intermediation and Performance: The Case of Egypt, Journal of Economics and Business, 61 (1), 70-89.

46. Orgler, Y. E. and Taggart, R. A. Jr. (1981): Implications of Corporate Capital Structure Theory for Banking Institutions, NBER Working Paper Series, Working paper, No. 737, August.

47. Osborne, M., Fuertes, A.-M. and Milne, A. (2012): Capital and Profitability in Banking: Evidence from US Banks. Working Paper Series. (Online: https:// www.cass.city.ac.uk/_data/assets/pdf file/0013/152122/Osborne_Matthew_ Capital-and-earnings-in-bankingEmerging-Scholars.pdf).

48. Pessarossi, P. and Weill, L. (2015): Do Capital Requirements Affect Cost Efficiency? Evidence from China, Journal of Financial Stability, 19, 119-127.

49. Prescott, E. S. (2001): Regulating Bank Capital Structure to Control Risk, Federal Reserve Bank of Richmond Economic Quarterly, 87 (3), 35-52.

50. PriceWaterHouseCoopers (2004): Study on the Financial and Macroeconomic Consequences of the Draft Proposed New Capital Requirements for Banks 
and Investment Firms in the EU, April. (Online: http://ec.europa.eu/internal_market/bank/docs/regcapital/ studies/2004-04-basel-impact-study_ en.pdf http://ec.europa.eu/internal_market/bank/docs/regcapital/studies/200404-basel-impact-study-annex_en.pdf)

51. Rochet, J. - C. (1992): Capital Requirements and the Behaviour of Commercial Banks, European Economic Review, 36 (5), 1137-1178.

52. Rodríguez, L. J. (2003): Banking stability and the Basel Capital Standards, Cato Journal, 23 (1), 115-126.

53. Ryen, G. T., Vasconcellos, G. M. and Kish, R. J. (1997): Capital Structure Decisions: What Have We Learned?
Business Horizons, September - October, 41-50.

54. Tabak, B. M., Fazio, D. M., Ely, R. A., Amaral, J. M. T. and Cajueiro, D. O. (2017): The Effects of Capital Buffers on Profitability: An Empirical Study, Economics Bulletin, 37 (3), 1468-1473.

55. Wall, L. D. and Peterson, P. P. (1998): The Choice of Capital Instruments, Federal Reserve Bank of Atlanta, Economic Review, Second Quarter, 4-17.

56. Witowschi, I. R. B. and Luca, F. A. (2016): Bank Capital, Risk and Performance in European Banking: A Case Study on Seven Banking Sectors, Prague Economic Papers, 25 (2), 127-142.

\title{
PROFITABILNOST HRVATSKIH BANAKA U UVJETIMA OTEŽANIH KAPITALNIH ZAHTJEVA
}

\begin{abstract}
Sažetak
Reguliranje ponašanja banaka korištenjem kapitalnih zahtjeva ključna je točka bonitetne regulative od kraja 1980-ih godina. Međutim, korisnost njenih efekata za sigurnost $i$ pouzdanost bankarskog sektora se osporava još od njihove inicijalne primjene, uglavnom zbog pretpostavkio negativnom utjecaju na bankovnu profitabilnost $i$ povećanju vjerojatnosti da će bankovni menadžeri biti skloniji riziku, posebno na visoko konkurentnim financijskim tržištima. S druge strane, na profitabilnost banaka djeluju brojni čimbenici, osim onih, koji se odnose na udovoljavanje za-

na profitabilnost hrvatskog bankarskog sektora, uzevši u obzir podatke iz 24 komercijalne banke, u vremenskog razdoblju od 2011 do 2016. Utjecaj regulacije kapitala na povrat na ukupnu imovinu i neto kamatnu maržu je bio pozitivan, dok je za povrat na vlasničku glavnicu utvrđena negativna veza. Zaključuje se da banke prebacuju troškove regulacije na svoje klijente, što se može aproksimirati neto kamatnom maržom. Nadalje, rezultati pokazuju da se ukupna profitabilnost banke postiže na trošak dioničara te se predlaže troškovno učinkovitiji pristup upravljanja bankama.
\end{abstract} htjevima regulacije kapitala. S obzirom na navedeni problem, u ovom se radu postavlja pitanje o utjecaju kapitalnih zahtjeva na profitabilnost banaka. Korištenjem dinamičke panel analize istražuju se posljedice regulacije bankovnog kapitala
Ključne riječi: kapitalni zahtjevi, profitabilnost banke, kapitalna struktura, komercijalne banke, dinamička panel analiza 


\section{Journal of Contemporary Management Issues}

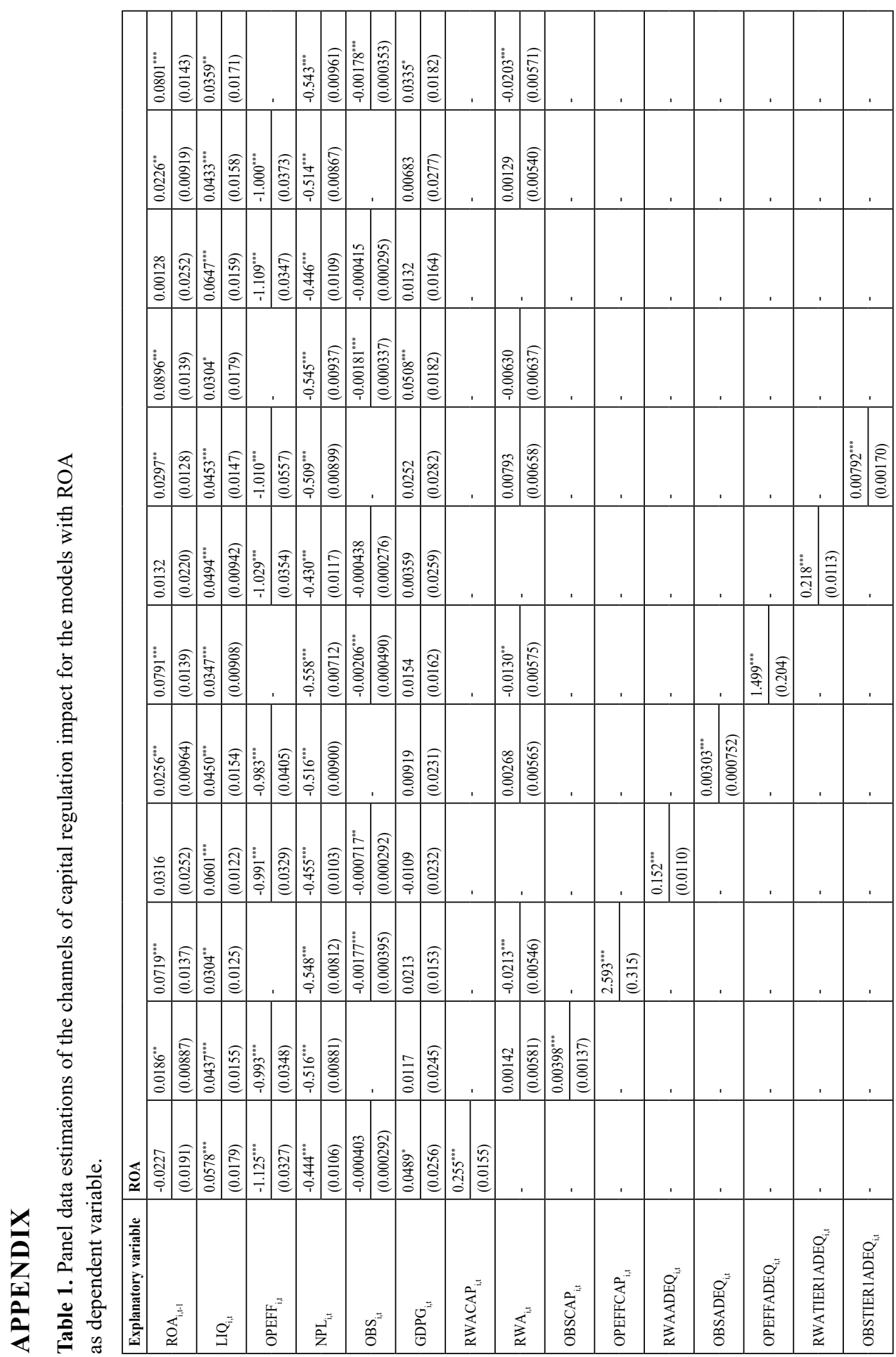


Management, Vol. 26, 2021, Special Issue, pp. 17-43

A. Kundid Novokmet, A. Pavić: CROATIAN BANKS PROFITABILITY UNDER CAPITAL ...

\begin{tabular}{|c|c|c|c|c|c|c|c|c|c|}
\hline i & ' & & 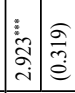 & 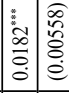 & $\exists$ & \ & 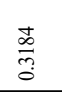 & 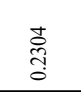 & $\stackrel{0}{\stackrel{2}{0}}$ \\
\hline ' & & 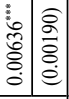 & & 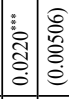 & $\exists$ & I & $\begin{array}{l}\infty \\
\infty \\
0 \\
0 \\
0\end{array}$ & $\begin{array}{l}\tilde{\Xi} \\
\stackrel{0}{0}\end{array}$ & $\begin{array}{l}\infty \\
\stackrel{\infty}{7} \\
0\end{array}$ \\
\hline i & 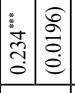 & . & & 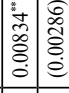 & 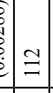 & I & 롱 & $\begin{array}{l}\text { तิ } \\
\text { d. }\end{array}$ & $\begin{array}{l}\text { ते } \\
\text { cे }\end{array}$ \\
\hline 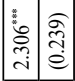 & . & & & 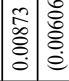 & $\cong$ & I & $\begin{array}{l}\text { 恶 } \\
\text { con }\end{array}$ & 䈍 & $\frac{\text { 娄 }}{0}$ \\
\hline ' & ' & & & 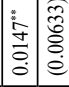 & $\cong$ & I & 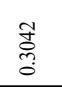 & $\stackrel{\infty}{\stackrel{\infty}{0}}$ & $\begin{array}{l}\text { 㕝 } \\
\text { 市 }\end{array}$ \\
\hline 1 & ' & & & 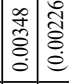 & $\cong$ & I & $\begin{array}{l}\text { त्. } \\
\text { م. }\end{array}$ & 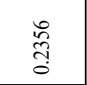 & $\frac{\text { dे }}{0}$ \\
\hline ' & ' & & & 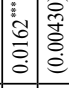 & 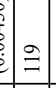 & I & $\begin{array}{l}\stackrel{t}{*} \\
\text { d }\end{array}$ & 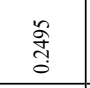 & $\begin{array}{l}\stackrel{0}{\circ} \\
\text { त̂ } \\
0\end{array}$ \\
\hline , & . & 1 & & 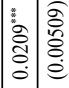 & 2 & I & 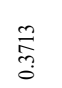 & $\begin{array}{l}\stackrel{\circ}{0} \\
\stackrel{0}{0}\end{array}$ & $\begin{array}{l}\vec{\sigma} \\
\hat{n} \\
0\end{array}$ \\
\hline ' & 1 & & ' & 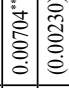 & 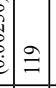 & I & 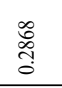 & $\begin{array}{l}\text { o. } \\
\text { กุ } \\
0\end{array}$ & $\begin{array}{l}\text { 索 } \\
\text { c. } \\
\end{array}$ \\
\hline ' & 1 & , & ' & 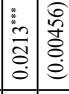 & 2 & I & $\begin{array}{l}\hat{f} \\
\text { ô. } \\
0\end{array}$ & 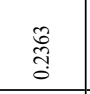 & $\begin{array}{l}\text { तี } \\
\text { ठ }\end{array}$ \\
\hline ' & ' & & & 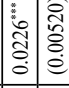 & 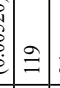 & I & $\begin{array}{l}\text { \&్ర } \\
0 \\
0\end{array}$ & $\frac{8}{\stackrel{0}{0}}$ & 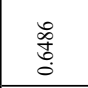 \\
\hline 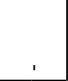 & . & & & 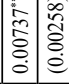 & 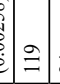 & I & $\begin{array}{l}\text { 导 } \\
\text { co } \\
0\end{array}$ & 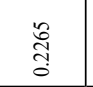 & 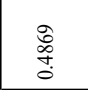 \\
\hline 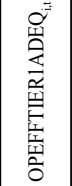 & 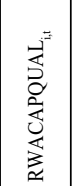 & 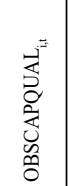 & 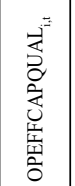 & $\sigma$ & 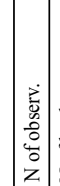 & 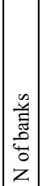 & 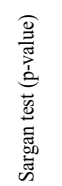 & 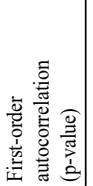 & 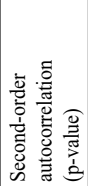 \\
\hline
\end{tabular}




\section{Journal of Contemporary Management Issues}

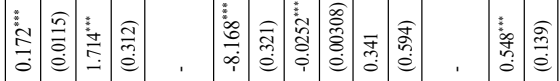

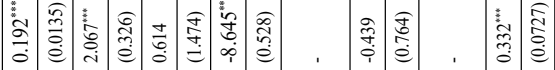

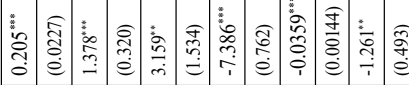

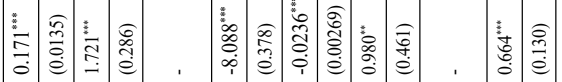

员福

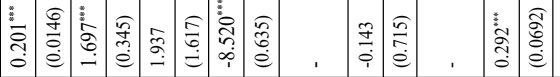

率高

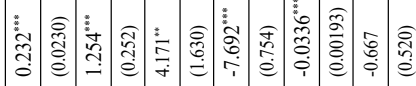

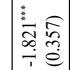

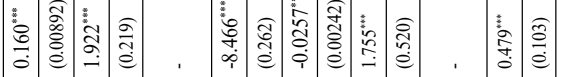

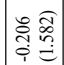

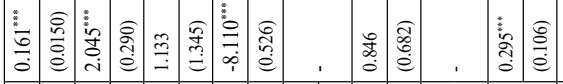

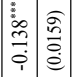

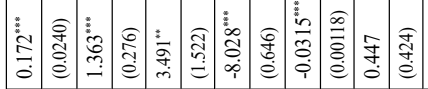

密眨

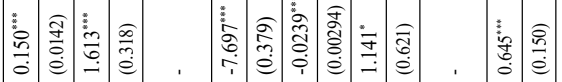

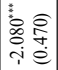

\section{至}

孛

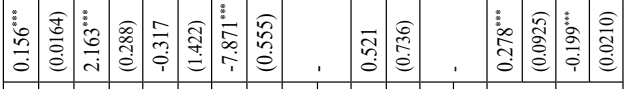

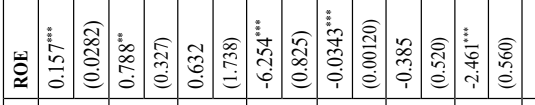

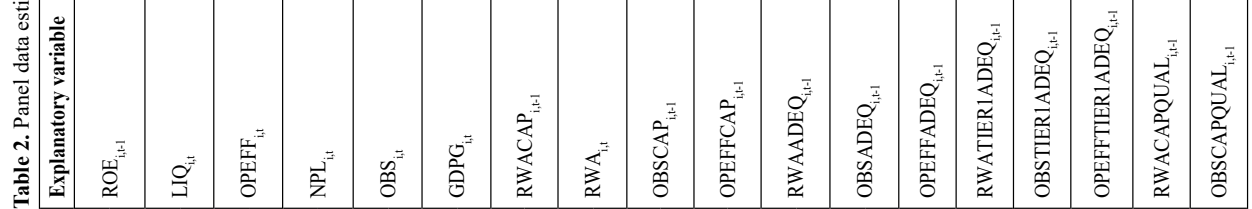




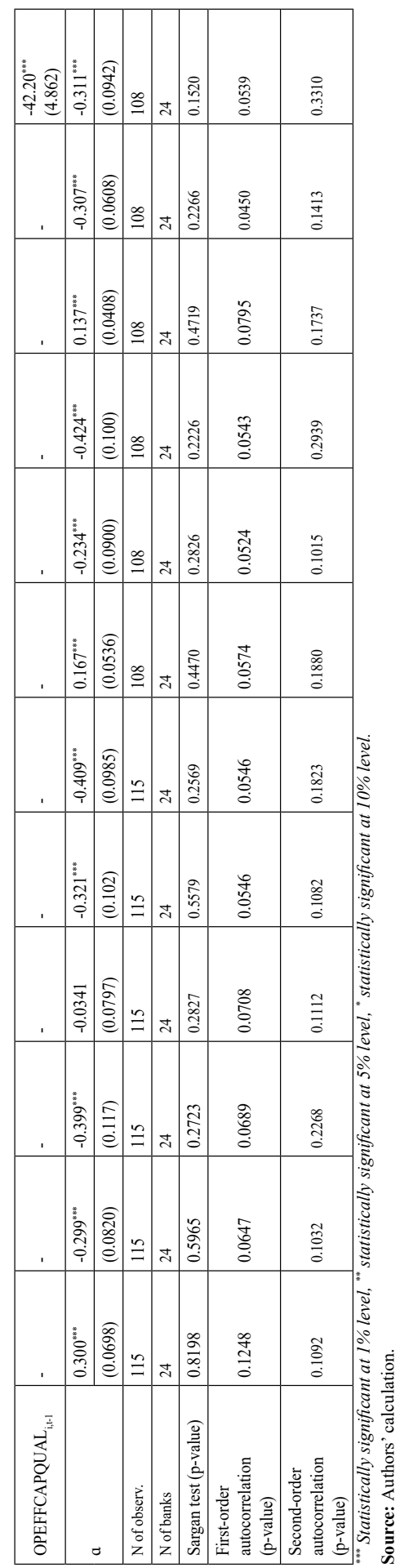


Journal of Contemporary Management Issues

\begin{tabular}{|c|c|c|c|c|c|c|c|c|c|c|c|c|c|c|c|c|c|c|c|}
\hline $\mid \begin{array}{l}0 \\
\vdots \\
5 \\
5 \\
0 \\
0\end{array}$ & 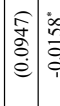 & 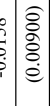 & ' & 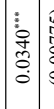 & 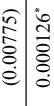 & 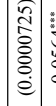 & 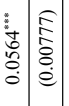 & ' & 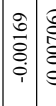 & & & & & & ' & & & & \\
\hline $\mid \begin{array}{l}1 \\
\vdots \\
\vdots \\
0 \\
0 \\
0 \\
0\end{array}$ & 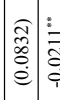 & 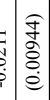 & 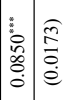 & $\begin{array}{l}\vdots \\
0 \\
0 \\
0 \\
0 \\
0 \\
0\end{array}$ & 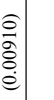 & 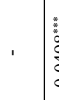 & 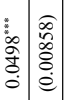 & ' & 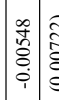 & 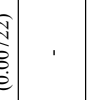 & & & & & ' & & ' & & 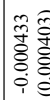 \\
\hline $\begin{array}{l}\vdots \\
\vdots \\
\hat{q} \\
0 \\
0 \\
0\end{array}$ & 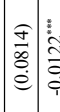 & 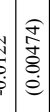 & 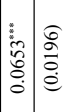 & $\mid \begin{array}{l}\vdots \\
f \\
0 \\
0 \\
0\end{array}$ & 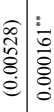 & 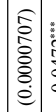 & 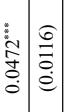 & ' & ' & & & & & & , & & & $\left|\begin{array}{lll}\vdots & & 0 \\
0 & 0 \\
0 & 0 & 0 \\
0 & 0 & 0 \\
0 & 0 & 0\end{array}\right|$ & \\
\hline $\begin{array}{l}\vdots \\
\vdots \\
\tilde{S} \\
\mathfrak{S} \\
0 \\
0\end{array}$ & 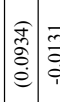 & 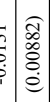 & ' & $\begin{array}{l}\vdots \\
\vdots \\
\vdots \\
\vdots \\
\vdots \\
\vdots\end{array}$ & 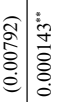 & 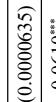 & 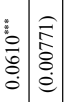 & ' & 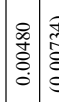 & & & & & & ' & & 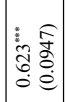 & & \\
\hline $\mid \begin{array}{c}\vdots \\
\vdots \\
b \\
0 \\
0 \\
0 \\
0\end{array}$ & 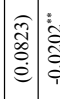 & 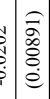 & 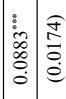 & 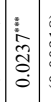 & 这 & & 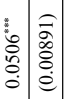 & . & 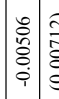 & E. & & & & &. & 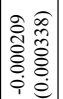 & & & \\
\hline $\mid \begin{array}{l}: \\
\vdots \\
0 \\
0 \\
0 \\
0\end{array}$ & 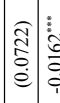 & 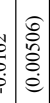 & 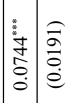 & $\mid \begin{array}{c}0 \\
\vdots \\
0 \\
0 \\
0 \\
0 \\
0\end{array}$ & 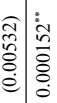 & 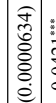 & 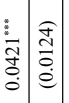 & ' & , & ' & & & & & 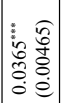 & & & & \\
\hline $\mid \begin{array}{c}\vdots \\
\vdots \\
o+\infty \\
0 \\
0 \\
0\end{array}$ & 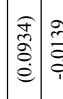 & 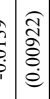 & ' & 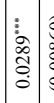 & 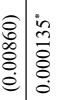 & $\left|\begin{array}{c|}0 \\
0 \\
0 \\
0 \\
0 \\
0 \\
0\end{array}\right|$ & 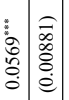 & ' & 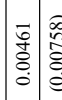 & $\begin{array}{l}6 \\
0 \\
\vdots \\
\vdots \\
\end{array}$ & & & ' & $\left|\begin{array}{cc}1 & \widehat{o} \\
\vdots & 0 \\
f & 0 \\
0 & 0 \\
0 & 0\end{array}\right|$ & ' & & , & ' & \\
\hline $\begin{array}{l}\vdots \\
\vdots \\
\infty \\
0 \\
0 \\
0\end{array}$ & 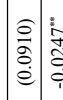 & 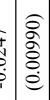 & 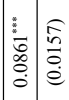 & 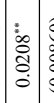 & 高 & & 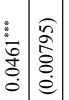 & , & 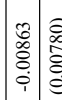 & $\begin{array}{c}6 \\
0 \\
0 \\
\\
\end{array}$ & & & 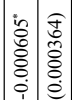 & & ' & & ' & & \\
\hline $\begin{array}{l}\vdots \\
\vdots \\
b \\
\vdots \\
0 \\
0 \\
0\end{array}$ & 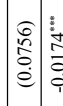 & 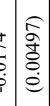 & 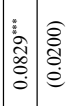 & 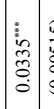 & 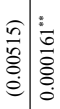 & 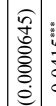 & 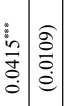 & ' & , & ' & & 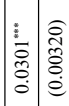 & & & ' & & & & \\
\hline $\begin{array}{l}: \\
\vdots \\
0 \\
\hat{q} \\
0 \\
0\end{array}$ & 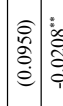 & 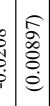 & ' & 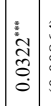 & 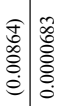 & 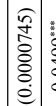 & 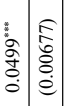 & ' & 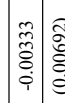 & $\begin{array}{l}5 \\
\vdots \\
6 \\
\vdots \\
\end{array}$ & 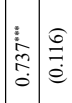 & & ' & ' & , & & ' & ' & \\
\hline \begin{tabular}{|l|}
$\vdots$ \\
$\vdots$ \\
$\vdots$ \\
$\vdots$ \\
0
\end{tabular} & 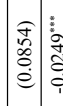 & 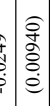 & 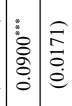 & 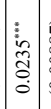 & 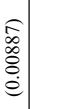 & & 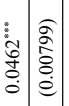 & . & \begin{tabular}{l|l} 
& 0 \\
0 & 0 \\
0 & 0 \\
0 & 0 \\
0 & 0 \\
0 & 0
\end{tabular} & 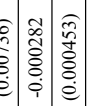 & & & & & ' & & & & \\
\hline $\begin{array}{l}\vdots \\
\vdots \\
\vdots \\
\vdots \\
0 \\
\vdots\end{array}$ & 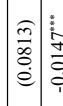 & 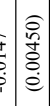 & 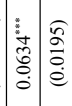 & $\begin{array}{c}\vdots \\
0 \\
\hat{c} \\
0 \\
0\end{array}$ & 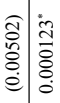 & 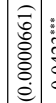 & 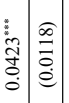 & 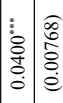 & , & ' & & & , & , & , & & , & ' & \\
\hline 党 & $\underline{z}$ & $\stackrel{\square}{g}$ & 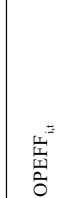 & $=$ & & 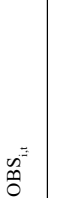 & $\begin{array}{l}0^{2} \\
\text { ड̃ }\end{array}$ & 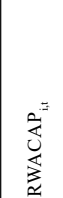 & ${ }_{2}^{3}$ & 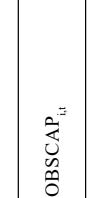 & 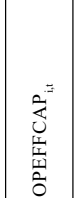 & 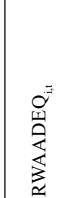 & 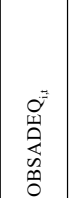 & 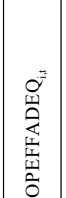 & 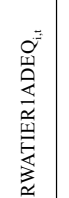 & 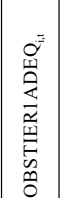 & 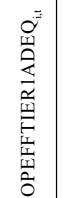 & 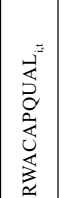 & 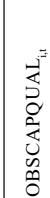 \\
\hline
\end{tabular}




\begin{tabular}{|c|c|c|c|c|c|c|}
\hline 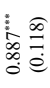 & $\begin{array}{l}: \\
\vdots \\
\vdots \\
\vdots \\
\vdots\end{array}$ & $\cong$ & & 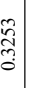 & $\begin{array}{l}\frac{0}{0} \\
\stackrel{0}{0}\end{array}$ & 発. \\
\hline & 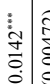 & $\cong$ & & 管 & $\begin{array}{l}\text { 学 } \\
\text { ò }\end{array}$ & 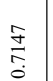 \\
\hline & $\begin{array}{l}\vdots \\
\vdots \\
0 \\
\vdots \\
\vdots \\
0\end{array}$ & $\cong$ & & 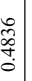 & 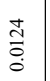 & $\begin{array}{c}0 \\
0 \\
0 \\
0 \\
0\end{array}$ \\
\hline & 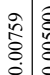 & $\cong$ & & 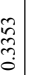 & $\begin{array}{l}\vec{b} \\
\overrightarrow{0} \\
0\end{array}$ & 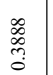 \\
\hline & 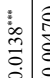 & $\cong$ & & 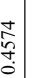 & 递 & إ. \\
\hline & $\begin{array}{cc}\vdots \\
\vdots \\
\infty \\
\vdots \\
\vdots \\
\vdots \\
0\end{array}$ & $\cong$ & & 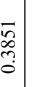 & $\begin{array}{l}\text { 品 } \\
\text { a. }\end{array}$ & $\begin{array}{l}\text { } \\
\hat{n} \\
3 \\
0\end{array}$ \\
\hline & $\begin{array}{l}0 \\
\vdots \\
\vdots \\
\vdots \\
0\end{array}$ & $\cong$ & & 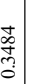 & $\begin{array}{l}\overrightarrow{\mathrm{g}} \\
\bar{a}\end{array}$ & \\
\hline & $\begin{array}{l}0 \\
\vdots \\
0 \\
0 \\
0 \\
0\end{array}$ & $\cong$ & & 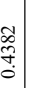 & 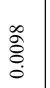 & $\begin{array}{l}\tilde{0} \\
\stackrel{0}{0}\end{array}$ \\
\hline & 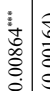 & $\cong$ & $\stackrel{\sim}{\triangleleft}$ & 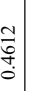 & $\begin{array}{l}\text { 壱 } \\
\stackrel{0}{0}\end{array}$ & 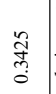 \\
\hline & 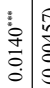 & $\stackrel{一}{=}$ & & 空 & 告 & 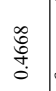 \\
\hline & 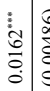 & $\cong$ & & స్ & $\begin{array}{l}\text { ôे } \\
\text { ô. }\end{array}$ & 㔼 \\
\hline & $\begin{array}{c}\vdots \\
\vdots \\
\vdots \\
\vdots \\
\vdots \\
0\end{array}$ & $\cong$ & $\dot{\Delta}$ & 产 & $\begin{array}{l}\text { I্ } \\
\stackrel{0}{0} \\
\stackrel{0}{0}\end{array}$ & 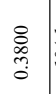 \\
\hline 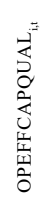 & $\sigma$ & 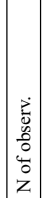 & 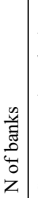 & 密 & 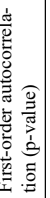 & 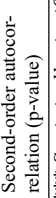 \\
\hline
\end{tabular}

